\title{
ARTICLE BH3-Only protein bmf is required for the maintenance of glucose homeostasis in an in vivo model of HNF1 $\alpha$-MODY diabetes
}

\author{
S Pfeiffer ${ }^{1}$, L Halang ${ }^{1}$, H Düssmann ${ }^{1}$, MM Byrne ${ }^{2}$ and JHM Prehn ${ }^{1}$
}

Heterozygous loss-of-function mutations in the hepatocyte nuclear factor $1 a$ (HNF-1a) gene can lead to diminished amounts of functional HNF-1a, resulting in the onset of a particularly severe form of maturity-onset diabetes of the young (MODY). We have previously shown that induction of a dominant-negative mutant of HNF-1a (DNHNF-1a) results in the activation of the bioenergetic stress sensor AMP-activated protein kinase (AMPK), preceding the onset of apoptosis and the induction of pro-apoptotic Bcl-2 homology domain-3-only protein Bmf (Bcl-2-modifying factor) as a mediator of DNHNF-1 $a$-induced apoptosis. Through the knockout of bmf in a transgenic mouse model with DNHNF-1a suppression of HNF-1a function in pancreatic beta-cells, this study aimed to examine the effect of loss-of-function of this $\mathrm{BH}$-only protein on the disease pathology and progression, and further elucidate the role of Bmf in mediating DNHNF-1a-induced beta-cell loss. Morphological analysis revealed an attenuation in beta-cell loss in bmf-deficient diabetic male mice and preserved insulin content. Surprisingly, bmf deficiency was found to exacerbate hyperglycemia in both diabetic male and hyperglycemic female mice, and ultimately resulted in a decreased glucose-stimulated insulin response, implicating a role for Bmf in glucose homeostasis regulation independent of an effect on beta-cell loss. Collectively, our data demonstrate that Bmf contributes to the decline in beta-cells in a mouse model of HNF1A-MODY but is also required for the maintenance of glucose homeostasis in vivo.

Cell Death Discovery (2015) 1, 15041; doi:10.1038/cddiscovery.2015.41; published online 5 October 2015

\section{INTRODUCTION}

Maturity-onset diabetes of the young (MODY) is a heterogeneous group of monogenic, non-insulin-dependent diabetes mellitus, characterized by autosomal dominant transmission and the development of severe hyperglycemia generally before the age of 25 years. $^{1}$ Of these, hepatocyte nuclear factor $1 a$ (HNF1a) -MODY is the most common and most severe. Patients are characterized by severe progressive hyperglycemia and beta-cell dysfunction, with impaired glucose-stimulated insulin secretion response by pancreatic beta-cells in contrast to insulin resistance by target tissues displayed by most NIDDM patients. ${ }^{1,2}$

HNF-1a is a dimeric, homeodomain-containing transcription factor involved in the control of expression of a wide variety of tissue-specific genes in the kidney, liver, spleen, intestine and pancreas, such as glucose transporter (Glut2) and insulin in the pancreatic beta-cell. ${ }^{3-7}$ Mutations the HNF-1a protein can lead to diminished amounts of functional HNF-1a through either haploinsufficiency or a dominant-negative mechanism and onset of the HNF1a-MODY phenotype. ${ }^{3,8,9}$ Several in vitro and in vivo models of various forms of MODY have been established utilizing these mutations to further elucidate the molecular mechanisms and progressive beta-cell dysfunction attributed to excessive betacell apoptosis observed in HNF1a-MODY. ${ }^{10-12}$

Apoptotic cell death is a hallmark of pancreatic beta-cell loss observed in all forms of diabetes mellitus, leading to the development of clinically overt disease. ${ }^{13,14}$ We and others have implicated caspase-dependent apoptotic pathways, along with activation of pro-apoptotic $\mathrm{Bcl}-2$ protein family members such as Bax, Bim, Bad and Puma as essential for the initiation of beta-cell apoptosis both in vitro and in vivo. ${ }^{10,15-19}$ Previously, we demonstrated induction of pro-apoptotic BH3-only protein Bmf (Bcl-2-modifying factor) expression during energetic stress in insulin-secreting cells and in the islets of dominant-negative HNF-1a (DNHNF-1a)-expressing transgenic mice, identifying Bmf as a primary mediator of DNHNF-1 $a$-induced apoptosis. ${ }^{15} \mathrm{Bmf}$ acts as an indirect activator of apoptosis, containing a single $\mathrm{BH} 3$ domain that interacts with prosurvival $\mathrm{BCl}-2$ proteins $\mathrm{BCl}-2, \mathrm{BCl}-\mathrm{xL}$ and $\mathrm{BCl}-\mathrm{w}$, preventing sequestration of direct activators such as Bid, Bim and Puma ${ }^{20,21}$ and has been shown to be induced as a result of AMP-activated protein kinase (AMPK) activation in response to bioenergetic stress to stimulate apoptosis, ${ }^{15,22}$ as well as having roles in autophagy and in cell death induced by high glucose levels in in vivo models of diabetes. ${ }^{23-25}$ In addition, Bmf has been shown to be induced post-transcriptionally through enhanced translation under conditions that cause repression of the CAP-dependent translation machinery, such as hyperglycemia. ${ }^{22,26}$

The current study was undertaken to elucidate the role of Bmf in mediating the progressive HNF-1a mutation-induced beta-cell death associated with HNF1a-MODY. Utilizing an established transgenic mouse model of HNF1a-MODY with a specific betacell-targeted DNHNF-1a mutation shown to result in glucose intolerance and overt diabetes, ${ }^{11,12}$ bmf expression was knocked out to examine the effect of loss-of-function of this BH3-only

${ }^{1}$ Department of Physiology and Medical Physics, Centre for Systems Medicine, Royal College of Surgeons in Ireland, 123 St. Stephen's Green, Dublin 2, Ireland and ${ }^{2}$ Department of Endocrinology, Mater Misericordiae University Hospital, 30 Eccles Street, Dublin 7, Ireland.

Correspondence: JHM Prehn (prehn@rcsi.ie)

Received 26 August 2015; accepted 29 August 2015; Edited by A Rufini 
protein on disease pathology and progression, and further elucidate the role of $\mathrm{Bmf}$ in mediating DNHNF-1 $a$-induced apoptosis.

\section{RESULTS}

Gene deficiency in bmf restores beta-cell mass and partially preserves insulin content in male DNHNF-1 $a$ transgenic mice In order to examine the role of Bmf in the progressive beta-cell dysfunction attributed to excessive beta-cell apoptosis observed in HNF1A-MODY, we introduced a bmf deficiency in a transgenic mouse model suppressed HNF-1a function in the pancreatic beta-cells ${ }^{11,12}$ to generate a transgenic bmf-deficient model of HNF1a-MODY (Figure 1a).

To assess the effect of bmf deletion on the pancreas, immunohistochemical analyses for insulin and glucagon expression were performed on pancreatic sections of bmf-expressing (DNHNF-1 $a^{b m f+/+}$ ) and bmf-deficient (DNHNF-1 $a^{b m f-/-}$ ) transgenic mice for analysis of islet structure. Representative images show double staining for 10-week-old male (Figures 1b-e) insulin- (red) and glucagon (green)-positive cells. In both sexes, deletion of bmf did not appear to have any effect on wild-type (WT) pancreatic sections that developed normally, displaying the typical islet architecture ${ }^{27}$ in both bmf-expressing (Figure 1b) and bmf-deficient (Figure 1d) WT groups. Upon examination of

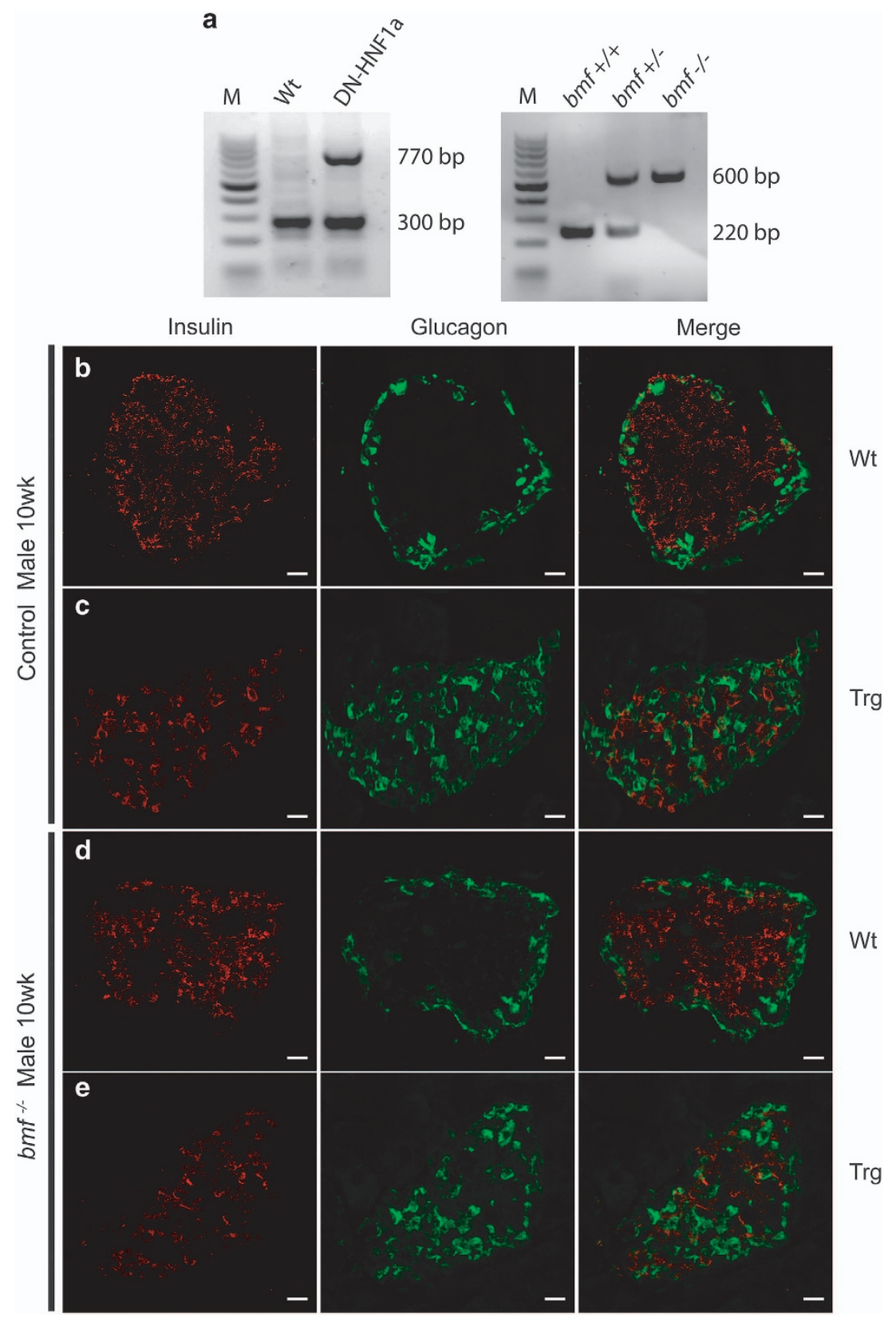

Figure 1. bmf deficiency partially rescues beta-cells in male DNHNF-1 $a$-induced diabetic islets. (a) Representative standard PCR analysis of genomic DNA for DNHNF-1 $a$ and bmf genotyping illustrating predicted band size. M, 100-bp marker. (b-e) The effect of bmf knockout on pancreatic islet organization was assessed in 10-week-old male mice. Representative images of bmf-expressing (b and c) and bmf-deficient (d and e) islets stained with anti-insulin and anti-glucagon antibodies for the identification of alpha-cell (green) and beta-cell(red) localization and organization within the pancreatic islet. $n=6$ islets per pancreas from $n=3$ per group. Scale bar, $50 \mu \mathrm{m}$. 
transgenic islets, disorganization of the islet is readily apparent, with a heterogeneous population of alpha-cells and beta-cells distributed throughout the islets in both DNHNF-1a groups (Figures $1 c$ and e). Glucagon-positive alpha-cells can be seen to migrate into the center of the islet, with insulin-positive beta-cells no longer localized to the core but also evident on the periphery. Analysis of distribution of glucagon relative to insulin staining (quantified using distance mapping in ImageJ) confirmed no significant rescue in islet cell disruption in bmf-deficient transgenic islets (data not shown).

Quantitative image analysis was used to assess the proportion of insulin- and glucagon-positive cells per islet. Whereas there were significantly fewer insulin-positive cells in male transgenic DNHNF-1 $a^{b m f++}(22.9 \pm 3.6 \%)$ compared with WT $(37.8 \pm 4.8 \%)$ islets, deletion of bmf resulted in an increased number of insulinpositive cells in transgenic DNHNF-1 $a^{\text {bmf- }--}$ islets $(33.5 \pm 6.5 \%)$, comparable to that of WT controls (Figure 2a). Deletion of bmf had no appreciable effect on the increased glucagon-positive cell number in either colony (Figure $2 \mathrm{~b}$ ). These findings were reflected in the observed ratio of alpha/beta-cells; significant alpha-cell expansion and decreased beta-cell fraction in DNHNF-1 $a^{b m f+/+}$ islets were reflected in an increased alpha/beta-cell ratio $(1.9 \pm 0.19)$ compared with $\mathrm{WT}^{\text {bmf+/+}}(0.53 \pm 0.09)$, and the rescue in the number of insulin-positive beta-cells in DNHNF-1 $a^{b m f-1-}$ islets was reflected in a significantly decreased alpha/beta-cell ratio $(0.99 \pm 0.13$; Figure $2 \mathrm{c})$. Similarly, we confirmed that no significant change in the ratio of alpha/beta-cells was observed in female islets in either group (Figure 2d), corresponding to the synchronously decreased alpha- and beta-cell fractions seen in female transgenic DNHNF-1 $a^{b m f-1-}$ islets.

In order to examine whether the increased cell mass observed was associated with increased pancreatic insulin content, we measured total pancreatic insulin content in non-fasted WT and DNHNF-1 $1 a$ mice aged 3 and 10 weeks. Pancreatic insulin content in bmf-expressing DNHNF-1a transgenic 3-week males was significantly lower $\left(36 \%\right.$ of $\mathrm{WT}^{b m f+/+}$ control); however, insulin content of DNHNF- $1 a^{b m f-/-}$ transgenic mice was not significantly reduced $\left(72.44 \%\right.$ of $\mathrm{WT}^{\mathrm{bmf-} /-}$ control, $\left.P=0.3\right)$, correlating with an increased beta-cell mass (Figure 3a). Subsequently, by 10 weeks rescue by deletion of bmf was no longer apparent, with insulin content significantly lower in both bmf-expressing $(57.1 \%$ $\mathrm{WT}^{b m f+/+}$ control) and bmf-deficient (57.9\% of $\mathrm{WT}^{\text {bmf-/- }}$ control) DNHNF-1v transgenic groups (Figure 3b).

\section{Deletion of bmf worsens glycemic control in DNHNF-1a transgenic} mice

Non-fasted blood glucose levels were monitored over a 10-week period. While no difference was observed in 3-week males (Figure 4a), by 6 weeks a significantly increased blood glucose level was apparent in both DNHNF-1a bmf-expressing $(16.9 \pm 2.8 \mathrm{mmol} / \mathrm{l})$ and $b m f$-deficient $(17.9 \pm 2.0 \mathrm{mmol} / \mathrm{l})$ groups compared with WT controls $(8.5 \pm 0.6$ and $9.3 \pm 1.2 \mathrm{mmol} / \mathrm{l}$, respectively); no distinguishable difference was observed between bmf-deficient and bmf-expressing control groups (Figure 4b). By 10 weeks, deletion of bmf significantly worsened already high blood glucose levels in DNHNF-1 ${ }^{b m f-/-}$ mice $(22.9 \pm 2.3 \mathrm{mmol} / \mathrm{l})$ compared with DNHNF-1 $a^{b m f+/+}$ control group $(16.5 \pm 0.8 \mathrm{mmol} / \mathrm{l})$ despite the rescue in beta-cell mass (Figure 4c).

To examine whether decreased glycemic control was related to beta-cell loss, non-fasted blood glucose levels in female mice were also monitored. Interestingly, female DNHNF-1 $a^{b m f-/-}$ mice also displayed increased glucose levels $(13.36 \pm 1.5 \mathrm{mmol} / \mathrm{l})$ compared with DNHNF-1 $1 a^{\text {bmft/+ }}$ control group $(9.23 \pm 0.44 \mathrm{mmol} / \mathrm{l})$ at 10 weeks versus WT controls $(9.8 \pm 0.5$ and $8.2 \pm 0.3 \mathrm{mmol} / \mathrm{l}$, respectively; Figure 4d).

Following these observations, in order to determine acute effects of bmf deficiency having an impact on insulin secretion and glucose tolerance, glucose tolerance tests were performed on 16 - $h$ fasted mice and changes in the blood glucose from basal fasting levels were measured over a period of $120 \mathrm{~min}$. Both male DNHNF-1 $a^{b m f+/+}$ and DNHNF-1 $a^{b m f-/-}$ mice exhibited

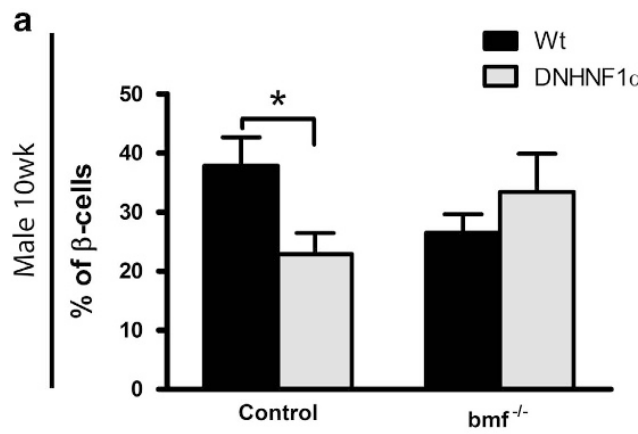

b
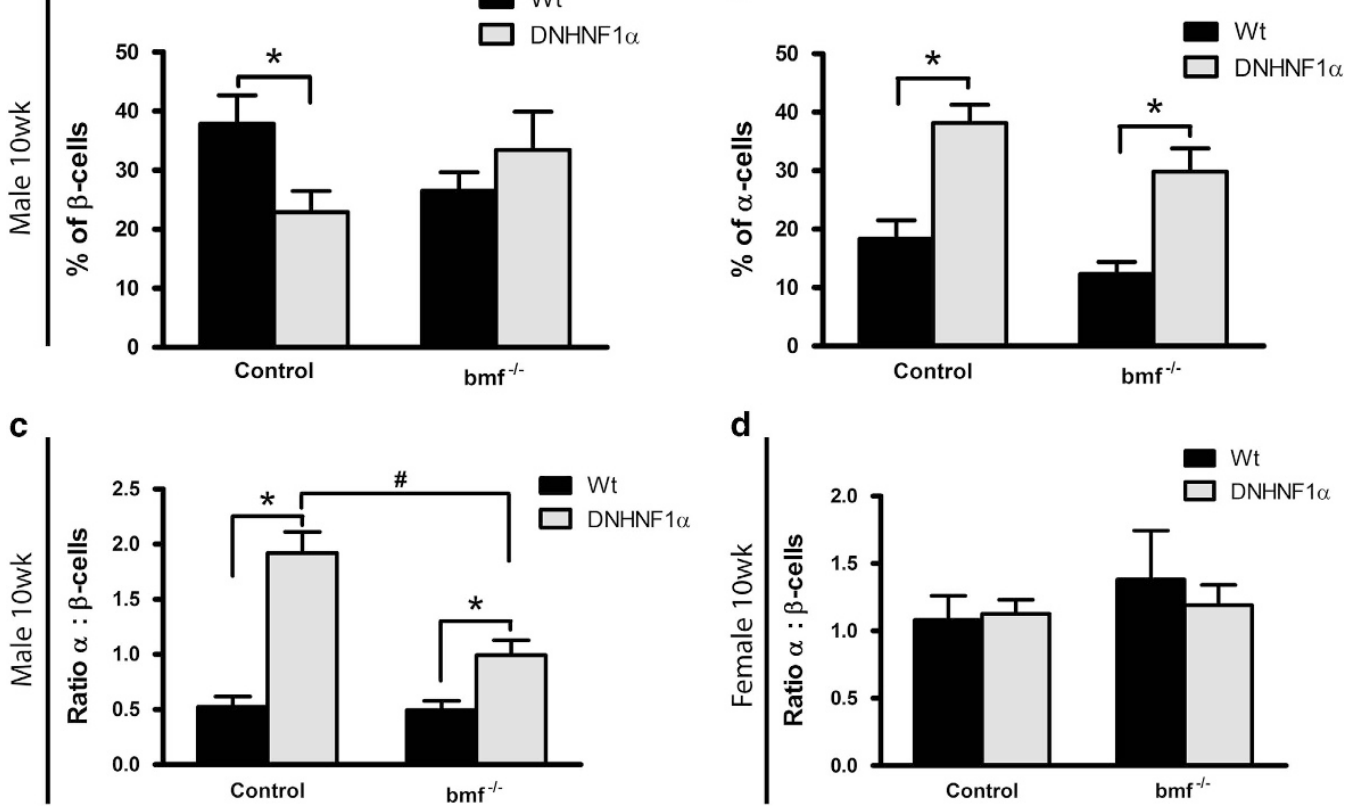

Figure 2. bmf knockout rescues beta-cell mass in male DNHNF-1 $a$ transgenic mice. Quantitative image analysis was used to assess the number of insulin-positive beta-cells (a) and glucagon-positive alpha-cells (b) in male 10-week-old immunostained pancreatic islets. (c and d), ratio of alpha-/beta-cells in male and female 10-week-old immunostained pancreatic islets, respectively. Data are presented as \% of alpha- and betacells normalized to cell number. $n=6$ islets per pancreas from $n=3$ per group. ${ }^{*} P<0.05$ compared with litter-matched controls; ${ }^{\#} P<0.05$ compared with matched bmf -expressing controls (ANOVA, post hoc Tukey's test). 

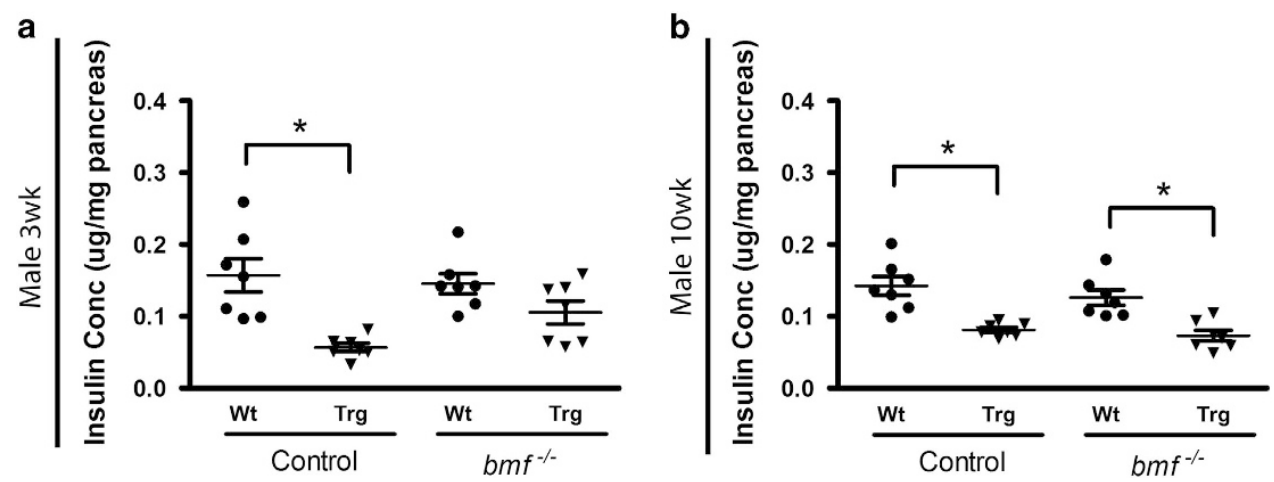

Figure 3. bmf knockout partially preserves pancreatic insulin content with rescue of beta-cell mass. Total pancreatic insulin content was measured in non-fasted male mice at (a) 3 and (b) 10 weeks of age by insulin ELISA. Data presented as mean \pm S.E.M. from $n=7$ per group. ${ }^{*} P<0.05$ compared with litter-matched controls (ANOVA, post hoc Tukey's test).
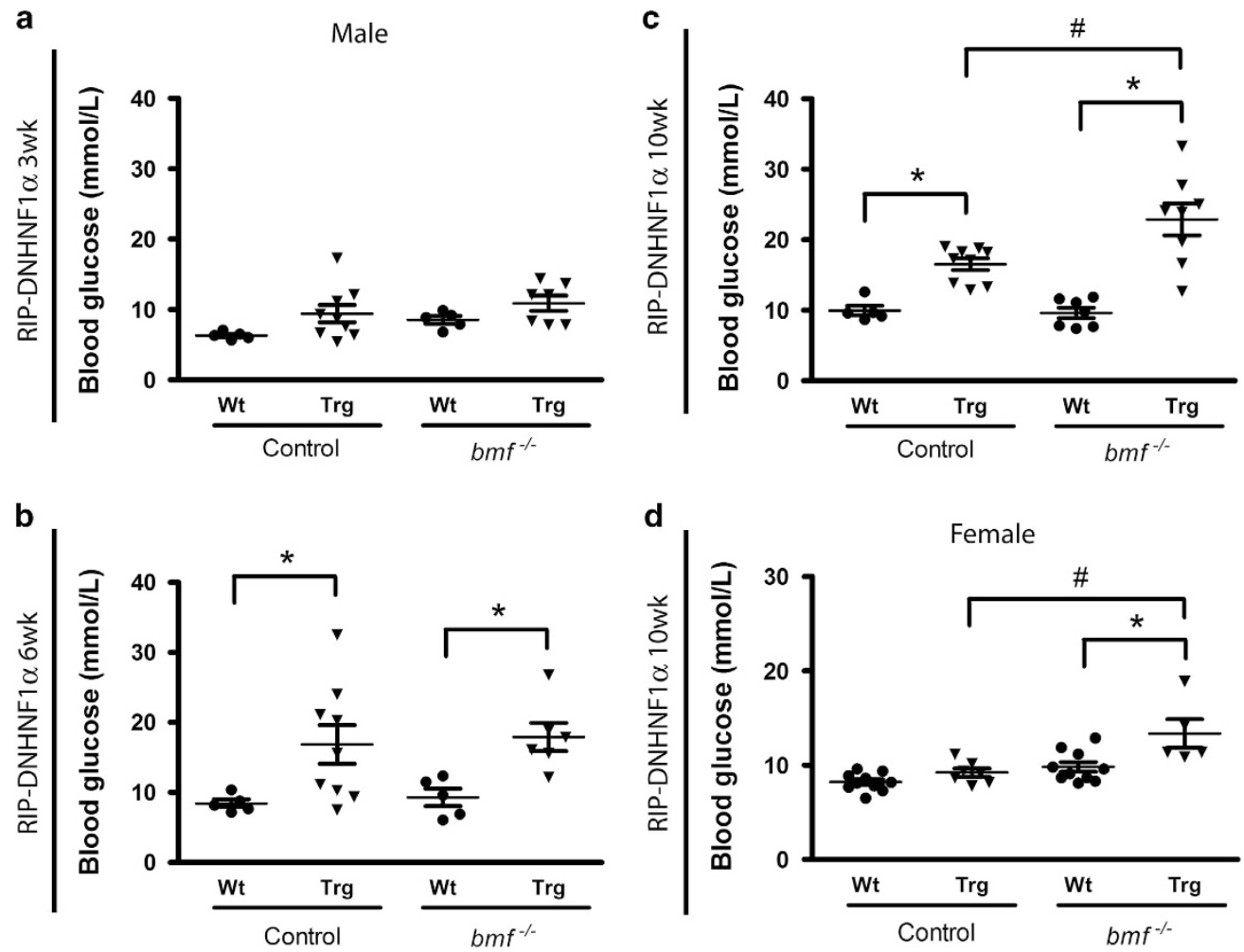

Figure 4. bmf knockout increases non-fasting blood glucose levels. Non-fasted blood glucose levels were measured at 3- (a), 6- (b) and 10 -week-old (c) male and female (d) mice. Transgenic DNHNF-1a mice deficient in bmf demonstrated increased blood glucose at 10 weeks compared with matched bmf-expressing transgenic DNHNF-1a controls in both colonies. Data presented as mean \pm S.E.M. from $n=5-10$ per group. ${ }^{*} P<0.05$ compared with litter-matched controls; ${ }^{\#} P<0.05$ compared with matched bmf-expressing controls (ANOVA, post hoc Tukey's test).

characteristic glucose intolerance from 3 weeks, with a 1.5 -fold increased reactive serum glucose from $30 \mathrm{~min}(28.2 \pm 2.1$ and $31.8 \pm 0.6 \mathrm{mmol} / \mathrm{l}$, respectively) compared with WT controls (18.1 \pm 1.9 and $21.4 \pm 1.3 \mathrm{mmol} / \mathrm{l}$; Figure $5 \mathrm{a}$ ). This was illustrated with area under the curve (AUC) assessment of glucose response profiles, which were unaffected by deletion of bmf (Figures $5 b$ and c). The reactive serum glucose profile was significantly increased at 6 weeks in both DNHNF-1 $1 a^{b m f+/}$ and DNHNF-1 $a^{b m f-/-}$ groups, maintained at $120 \mathrm{~min}$ post administration $(23.2 \pm 2.3$ and $22.1 \pm 0.9 \mathrm{mmol} / \mathrm{l}$, respectively) compared with WT controls $(9.9 \pm 0.5$ and $10.4 \pm 0.6 \mathrm{mmol} / \mathrm{l}$; Figures $5 \mathrm{~d}$, e, f). By 10 weeks, both transgenic groups displayed increased basal (14.6 \pm 0.9 and $13.3 \pm 0.9 \mathrm{mmol} / \mathrm{l})$ and reactive serum glucose $(26.1 \pm 2.7$ and $23.3 \pm 3.9 \mathrm{mmol} / \mathrm{l}, 120 \mathrm{~min})$ compared with WT controls $(10.0 \pm 0.4$ and $10.6 \pm 0.7 \mathrm{mmol} / \mathrm{l}, 0 \mathrm{~min} ; 11.6 \pm 1.1$ and $10.4 \pm 1.3 \mathrm{mmol} / \mathrm{l}, 120$ min; Figures $5 \mathrm{~g}-\mathrm{i})$. Homeostatic model assessment of beta-cell function (HOMA- $\beta$ ) showed that, despite restoring decreased betacell mass, deletion of bmf had no significant effect on decreased basic insulin secretion function $\left(P=1.0\right.$ between DNHNF-1 $1 a^{b m f+/+}$ and DNHNF-1 $a^{\text {bmf-1- }}$ groups at 3, 6 and 10 weeks).

Female mice displayed a similarly impaired glucose response profile; deletion of bmf worsened DNHNF-1a glycemic control at 


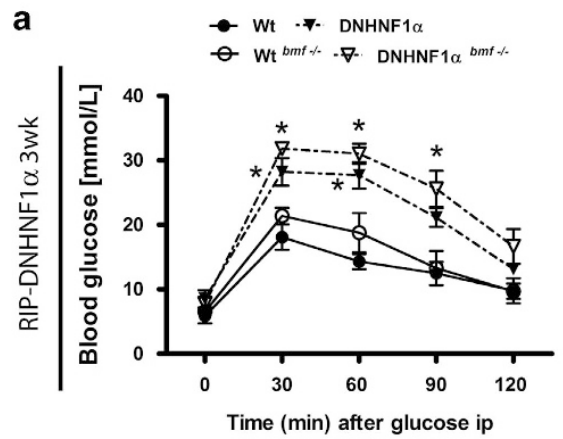

b

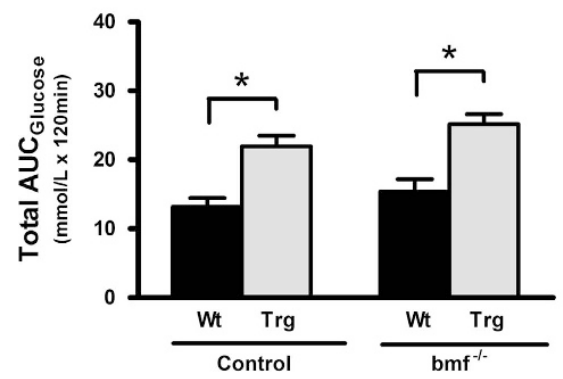

e
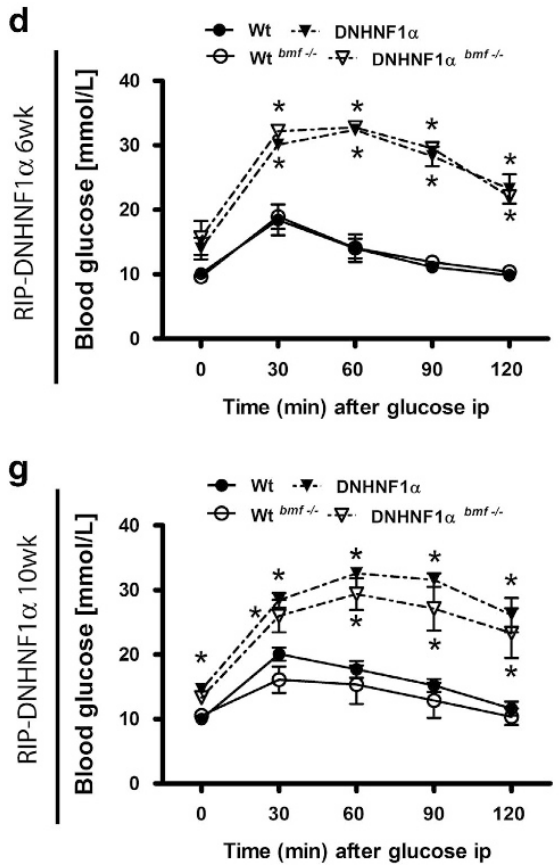

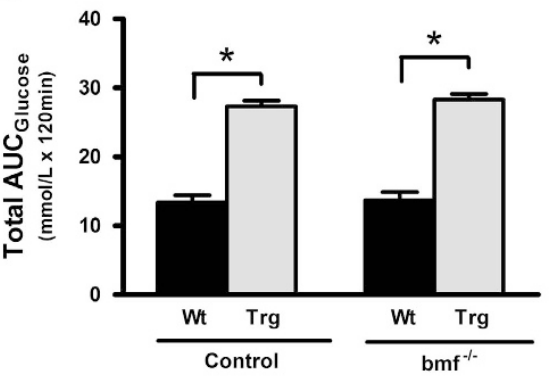

h

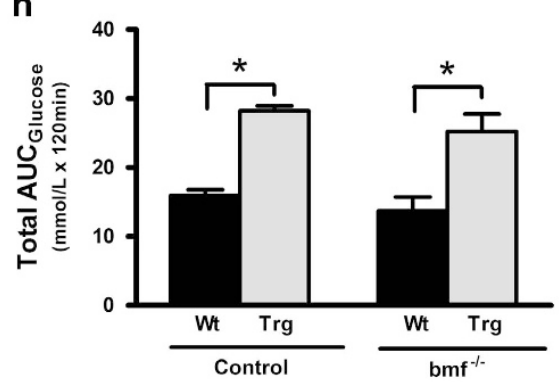

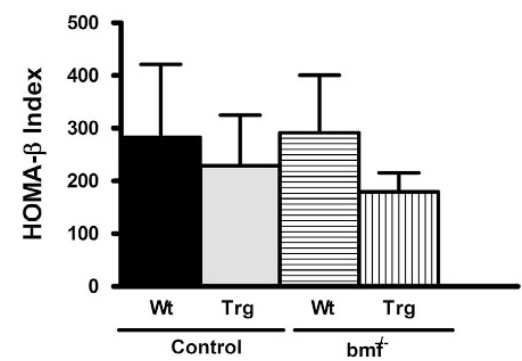

f

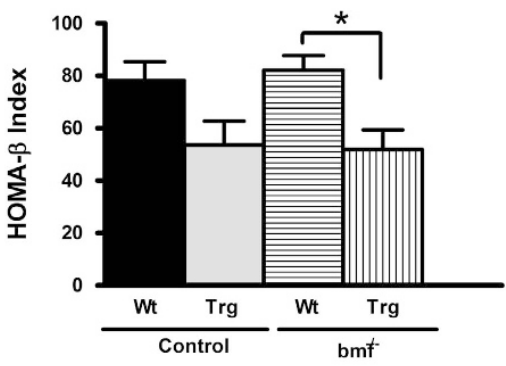

i

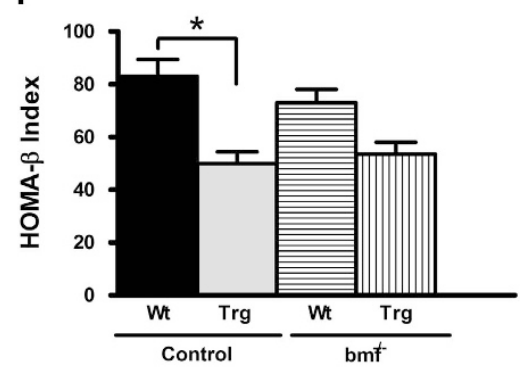

Figure 5. bmf deficiency does not attenuate increased serum glucose concentrations in male DNHNF-1a transgenic mice during intraperitoneal glucose tolerance test. Change in the blood glucose from fasting levels was determined over a 2-h period after i.p. injection of

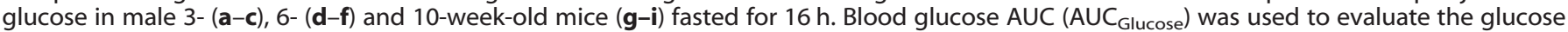
clearance rate. Homeostatic model was used to assess beta-cell function (HOMA- $\beta$ ) during intraperitoneal glucose tolerance test. Data are presented as the mean change in blood glucose levels \pm S.E.M. $n=6-7$ per group. ${ }^{*} P<0.05$ compared with litter-matched controls (ANOVA, post hoc Tukey's test).

3 weeks $(17.7 \pm 2.7 \mathrm{mmol} / \mathrm{l}, 120 \mathrm{~min})$ compared with DNHNF-1 $a^{\text {bmf+/+ }}$ $(10.7 \pm 2.2 \mathrm{mmol} / \mathrm{l}, 120 \mathrm{~min})$ and similarly showed no significant effect on beta-cell function to 10 weeks.

Attenuation of bmf expression decreases glucose-stimulated insulin secretion

Despite beta-cell preservation, the observed lack of corollary effect on glucose homeostasis led us to examine whether deletion of bmf in beta-cells leads to a specific insulin secretion defect. Basal and secreted insulin at $15 \mathrm{~min}$ was therefore also assessed in response to glucose challenge. Although no difference in fasted insulin levels was observed at 3 weeks, deletion of bmf did not confer any improvement in DNHNF-1a-decreased insulin response levels in DNHNF-1 $a^{b m f-/-}$ or WT $T^{b m f-/-}$ mice $(P=1.0$ compared with DNHNF-1 $a^{\text {bmft/+}}$; Figures $6 a$ and b). By 10 weeks, bmf deficiency remained ineffectual in having an impact on decreased insulin secretion observed in DNHNF-1 $a^{b m f+/+}(1.1 \pm 0.02 \mu \mathrm{g} / \mathrm{l})$ and DNHNF-1 $a^{\text {bmf-/- }}(1.1 \pm 0.03 \mu \mathrm{g} / \mathrm{l})$ and was also observed to decrease glucose-stimulated insulin secretion in $\mathrm{WT}^{\text {bmf-/- }}$ $(1.1 \pm 0.04 \mu \mathrm{g} / \mathrm{l})$ compared with $\mathrm{WT}^{b m f+/+}$ control $(1.3 \pm 0.06 \mu \mathrm{g} / \mathrm{l}$;
$P=0.01$ for all groups compared with WTbmft/+; Figure 6c). Calculation of the HOMA index of degree of insulin resistance (HOMA-IR) demonstrated decreased insulin sensitivity in transgenic DNHNF-1 $a^{b m f++}$ mice $(13.2 \pm 3.2)$ compared with $\mathrm{WT}^{b m f+/+}$ $(7.3 \pm 1.5)$, not rescued by deletion of bmf (DNHNF-1 $a^{b m f-/-}$ $P=1.0$, WT $\left.^{\text {bmf }-/-} P=0.7\right)$.

\section{DISCUSSION}

Progressive beta-cell dysfunction and cell death, with impaired glucose-stimulated insulin secretion response and resulting hyperglycemia, is the hallmark and primary cause of diabetes and chronic related complications observed in HNF1a-MODY patients. Previous findings from our laboratory linking potent proapoptotic activity of Bmf to DNHNF-1a-induced apoptosis present it as an attractive target for investigation into NIDDM-associated stress-induced beta-cell death. Among pro-apoptotic BH3-only proteins implicated in cell death, the role of Bmf, induced as a result of AMPK activation in response to bioenergetic stress in vitro ${ }^{15}$ and mitochondrial ROS-mediated high glucose-induced upregulation in in vivo models of diabetes, ${ }^{25}$ still remains poorly 

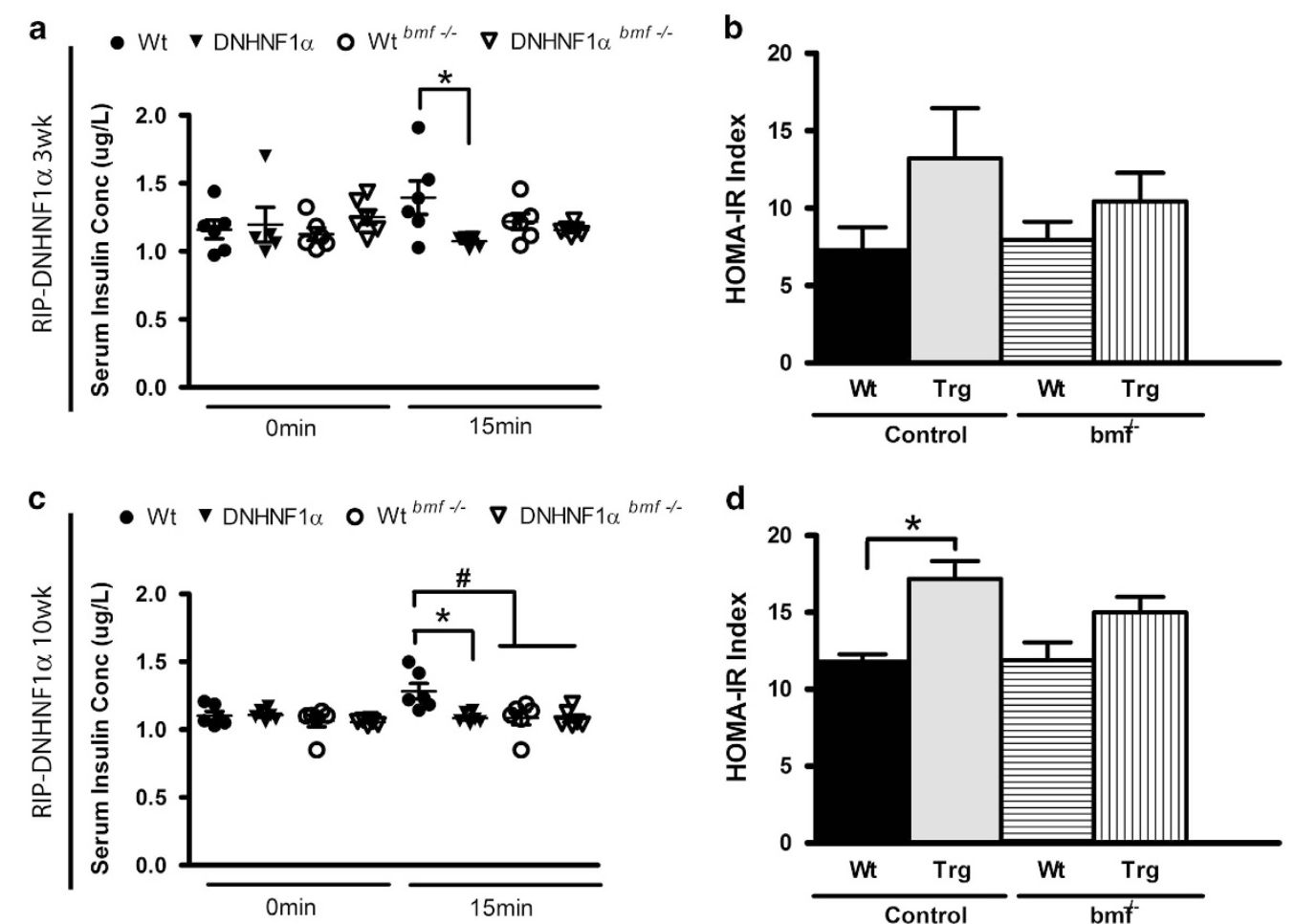

Figure 6. Deletion of bmf expression decreases serum glucose-stimulated insulin secretion. The change in serum insulin from fasting levels was determined at 0 and 15 min after i.p.GTT in male 3- (a and b) and 10-week-old mice (c and d) fasted for 16 h. Homeostasis model was used to assess insulin resistance (HOMA-IR) during intraperitoneal glucose tolerance test. Data are presented as the mean change in insulin levels \pm S.E.M. $n=6-7$ per group. ${ }^{*} P<0.05$ compared with litter-matched controls; ${ }^{\#} P<0.05$ compared with matched $b m f$-expressing controls (ANOVA, post hoc Tukey's test).

investigated. Of note, Bmf has also been shown to have a role in endocrine tissue homeostasis of gastrointestinal epithelial cells. ${ }^{28}$ To investigate the consequences of bmf deletion on impaired HNF- $1 a$ function, we introduced a bmf deficiency in an established model of suppressed HNF-1a function in the beta-cells of mice. Our data conclude that deletion of Bmf results in a rescue of the progressive beta-cell death observed in HNF1a-MODY. However, attenuation of bmf expression results in an observable insulinsecretory defect, indicating that Bmf is required for insulin secretion, counteracting any rescues in beta-cell decrease.

Maintenance of islet architecture is important to the normal and pathological functioning of the islet; disruption to the preferential homologous contact between beta-cells carries functional implications for paracrine function, critically having an impact on betacell mass and insulin secretion. ${ }^{29,30}$ Interestingly, bmf deficiency resulted in a restoration of beta-cell mass in diabetic transgenic DNHNF-1a islets, which is reflected in a significantly decreased alpha/beta-cell ratio compared with that observed in bmfexpressing DNHNF-1a counterparts. Despite this partial recovery, the effect observed on increased glucose levels or insulin secretion response was negatory and the adjuvant heterologous disorganization of islet structure remained unaffected by attenuation of Bmf expression. Changes in the cellular location, resulting in disruption to specific interactions and connections with the extracellular matrix (ECM) and cell-cell junctions associated with tissue architecture, can alter signaling pathways associated with cell survival and result in anoikis through activation of $\mathrm{BH}$-only proteins and initiation of apoptosis to maintain tissue integrity and homeostasis. ${ }^{31}$ Previous studies have identified Bmf as a central regulator of anoikis, ${ }^{20}$ and significant upregulation of bmf has been observed upon anoikis induction through the disruption of cell-cell and cell-ECM contacts in human intestinal epithelial cells. $^{21}$ Therefore, it is possible that Bmf may directly regulate anoikis in response to loss of, or inappropriate, cell-cell or cellECM interactions by acting as a sensor for actin cytoskeleton integrity in addition to its role as a mediator of energetic stressinduced apoptosis.

Previous studies aiming to elucidate the roles of $\mathrm{BH} 3$-only proteins as key modulators of beta-cell apoptosis have implicated members such as Bim and Puma in beta-cell apoptosis but also demonstrated an extensive degree of reciprocal functional redundancy. Studies in mouse models of $\mathrm{Pdx} 1$ haploinsufficiency found increased expression of Bim and Puma, and suppression of these genes showed improved glucose tolerance, enhanced betacell mass and reduced apoptotic cell death both in in vivo and in vitro. ${ }^{32}$ Similarly, significantly higher levels of Bim and Puma mRNAs have been observed in islets of human donors with type 2 diabetes, and mice deficient in Bim and Puma were significantly protected from high glucose-induced islet cell death. ${ }^{18,19}$ Loss of other BH3-only proteins Bid or Noxa had no impact on glucoseinduced apoptosis. ${ }^{18,33}$ It is therefore possible that other BH3-only proteins also contribute to beta-cell apoptosis in the DNHNF1a mouse model, in particular at late disease stages.

Examination of homeostatic non-fasted blood glucose found that deletion of bmf significantly aggravates DNHNF-1 $a$-induced hyperglycemia. This dysregulation was accompanied by declining pancreatic insulin content; however, it should be noted that the significant increases in blood glucose in bmf-deficient transgenic mice were not reflected in further reduced insulin content. In fact, at 3 weeks total pancreatic insulin content was initially preserved by deletion of bmf; however, this was no longer apparent by 10 weeks, most likely because of a compensatory mechanism whereby other BH3-only proteins substitute for Bmf deficiency as discussed above. Subsequent studies examining glucose tolerance 
demonstrated severe glucose intolerance in DNHNF-1 $a$ transgenic mice, and bmf deficiency was not observed to have any restorative effect. Similarly, gene deficiency had no effect on the adherent glucose-stimulated insulin secretion response; despite the development of increased basal glucose levels and severe hyperglycemia during glucose challenge, bmf deficiency remained ineffectual in having an impact on decreased insulin secretion, even lowering the response of bmf-deficient WT mice.

The transcriptional upregulation of Bmf in response to energetic stress and high glucose levels in vitro and in vivo suggest a role for Bmf in the maintenance of glucose homeostasis mechanisms. Impaired glucose response profiles, combined with the failure of bmf deletion to confer any improvement in decreased insulin response levels in either DNHNF-1 $a$ or WT mice despite initially increased total pancreatic insulin content, implicate a 'day-time' role for Bmf in functional beta-cell insulin secretion unrelated to cell death. These overlapping functions of Bmf, in both glycemic control and beta-cell apoptosis, combine upon bmf deletion to present the preserved beta-cell mass with attendant hyperglycemic glucose-intolerant profiles that we observed. Other studies have demonstrated similar outcomes through manipulation of mediators of beta-cell apoptosis. Overexpression of anti-apoptotic $\mathrm{Bcl}-2$ family protein $\mathrm{Bcl}-\mathrm{xl}$, despite preventing beta-cell apoptosis, resulted in consequentially impaired glucose-induced insulin secretion and hyperglycemia because of defective mitochondrial nutrient metabolism and insulin secretion signaling. ${ }^{34}$ Similarly, loss-of-function of $\mathrm{BCl}-2$ and $\mathrm{Bcl}-\mathrm{xL}$ in single and double Bax-Bak knockout beta-cells was demonstrated to significantly augment glucose-induced insulin secretion and glucose-dependent metabolic signals, suggesting a dampening of beta-cell response to glucose by prosurvival $\mathrm{Bcl}-2$ proteins and a role for core apoptotic proteins in beta-cell physiology. ${ }^{35}$ The mechanism responsible for the effects of Bmf on beta-cell function may be mediated though a defect in mitochondrial metabolism, which has a crucial role in the stimulus-secretion coupling of glucose-induced insulin secretion in pancreatic beta-cells. Given the subcellular localization of $\mathrm{BCl}-\mathrm{xL}$ to the mitochondrial membrane ${ }^{36}$ and effects on mitochondrial function, ${ }^{37-40}$ the loss of Bmf and its interaction with $\mathrm{BCl}-\mathrm{xL}$, and indeed $\mathrm{BCl}-2$ and $\mathrm{BCl}-\mathrm{W}$, may be related to disturbances in mitochondrial signaling-mediating glucose-induced insulin secretion.

Collectively, our data point to a role for Bmf in having an impact on pancreatic beta-cell survival, but also contributing to pancreatic beta-cell function independent of cell death signaling.

\section{METHODS}

\section{Gene-targeted mice}

Beta-cell-specific suppression of HNF-1a function was achieved using the rat insulin promoter (RIP) II to directly drive targeted overexpression of a dominant-negative mutant of HNF-1a (DNHNF-1a) in transgenic mice, a generous gift from Professor C.Wollheim (Centre Médical Universitaire, Geneva, Switzerland). ${ }^{3,11}$ Targeted $\mathrm{bmf}^{-/-}$mutant mice originally generated from C57BL/6-derived Bruce4 ES cells backcrossed onto a C57BI/6 J background were provided by Professor Andreas Strasser (WEHI, Melbourne, Australia). ${ }^{23}$ To generate mice deficient for $\mathrm{Bmf}, \mathrm{bmf}^{-{ }^{-}}$mice were crossed with RIP-DNHNF-1a mice to produce mice heterozygous for both alleles (RIP-DNHNF-1 $a^{+/-} b m f^{+/-}$) and were intercrossed to generate Bmf-deficient RIP-DNHNF-1 $a^{+/-} b m f^{-1-}$ mice. As controls, WT and heterozygous RIP-DNHNF-1 $a$ mice expressing endogenous bmf were used. All mouse strains were backcrossed for $>10$ generations on an inbred C57BL/6 background. Animal experiments were carried out under license from the Department of Health and Children (Ireland) and in accordance with the Principles of Laboratory Animal Care and local Research Ethics Committee.

\section{Genotype analysis}

Wild-type, transgenic and knockout alleles for DNHNF-1 $a$ and bmf were confirmed using PCR analysis of genomic DNA extracted from tail snips using High Pure PCR Template Preparation Kit (Roche, Basel, Switzerland). Genotyping was performed using the following specific primers: $5^{\prime}-\mathrm{GGA}$ GTTCAGACTTCGCCGAGAG-3', 5'-GGCTGGTCACAAAGTTTGACACTG-3' (WT allele-specific); 5'-GGAGTTCAGACTTCGCCGAGAG-3', 5'-GCAAGAGGCAAG CCCTTCACTTGG-3' (mutant allele-specific) for $b m f$ and $5^{\prime}$-CTGCTAACCATGT TCATGCCT-3' (sense), 5'-TGAATTGCTGAGCCACCTCTC-3' (mutant allelespecific reverse) for DNHNF-1a.

\section{Confocal microscopy and immunohistochemistry}

Morphometric analysis was carried out on age- and sex-matched animals aged 10 weeks. Mice were killed by cervical dislocation and the pancreas was dissected out, snap-frozen and stored at $-80^{\circ} \mathrm{C}$. Pancreatic cryostat sections $(12 \mu \mathrm{m})$ were processed for double-immunofluorescence staining for detection of insulin and glucagon. Briefly, sections were incubated $2 \mathrm{~h}$ with diluted polyclonal guinea pig anti-insulin (1:100, Dako Diagnostics, Glostrup, Denmark) or monoclonal rabbit anti-glucagon $(1: 100$, Cell Signalling Technology, Danvers, MA, USA) antibodies at RT. Sections were subsequently incubated at RT for $1 \mathrm{~h}$ with an Alexa 568-conjugated antiguinea pig or Alexa 488-conjugated anti-rabbit secondary antibody (1 :500, Invitrogen, Waltham, MA, USA) and mounted in VECTASHIELD Mounting Media with DAPI (4',6-diamidino-2-phenylindole; Vector Labs, (A, USA). Images were acquired on a Zeiss-LSM510 confocal microscope (Carl Zeiss, Jena, Germany) as previously described, ${ }^{41}$ and analysis was carried out using the ImageJ software (version 1.48, NIH, http://imagej.nih. $\mathrm{gov} / \mathrm{ij} /$ ). For analysis of pancreatic sections, $z$-stack images of each islet imaged were generated, and number of insulin- or glucagon-positive cells per islet and alpha/beta-cell ratio were determined using integrated z-projection. Percentage of insulin-positive or glucagon-positive cells within each islet was quantified by number of cells stained positive for the protein of interest normalized to cell number, and from this the ratio of alpha/beta-cells was calculated. Otsu was used to segment immunostained and background areas from another, and areas above threshold were then used for quantification. The cell number was determined by number of nuclei per islet.

\section{Pancreatic insulin content}

Pancreatic insulin content was determined from 3- and 10-week age- and sex-matched animals. Snap-frozen pancreata were weighed and insulin was extracted with cold acid-ethanol. Briefly, pancreata were incubated $\mathrm{O} / \mathrm{N}$ in acid-EtOH $(1.5 \% \mathrm{HCl}$ in $70 \%$ ethanol $)$ at $-20^{\circ} \mathrm{C}$, and then homogenized and incubated $\mathrm{O} / \mathrm{N}$ at $-20^{\circ} \mathrm{C}$. Samples were centrifuged 15 min 2000 r.p.m. at $4{ }^{\circ} \mathrm{C}$ and supernatant removed and neutralized with $1: 1$ volume TRIS (1M pH7.5). Insulin content in acid-ethanol supernatant was determined with Ultrasensitive Mouse Insulin ELISA (Mercodia AB, Uppsala, Sweden).

\section{Non-fasting glycemic blood measurements}

Homeostatic blood glucose levels were measured in age- and sex-matched animals at 3-, 6- and 10-week time points using Bayer CONTOUR Blood Glucose Meter (Bayer Diabetes Care, Dublin, Ireland). A small drop of blood $(\sim 0.6 \mu \mathrm{ll})$ from the tail vein was collected and blood glucose value recorded $(\mathrm{mmol} / \mathrm{l})$. All procedures were carried out in a blinded manner.

\section{Intraperitoneal glucose tolerance tests}

Age- and sex-matched mice aged 3, 6 and 10 weeks were fasted overnight for $\sim 16 \mathrm{~h}$, weighed and subsequently injected intraperitoneally with glucose $(2 \mathrm{~g} / \mathrm{kg}$ body weight). For glucose tolerance tests, blood glucose levels were measured at $0,30,60,90$ and 120 min post injection from tail vein blood as described above. For insulin release studies, blood was collected at 0 and $15 \mathrm{~min}$ post injection. Serum insulin levels were measured with Ultrasensitive Mouse Insulin ELISA (Mercodia AB). All procedures were carried out in a blinded manner.

\section{Insulin release studies}

For insulin release studies, measurement of serum insulin concentration during Intraperitoneal glucose tolerance test (ipGTT) was performed by blood collection at 0 and $15 \mathrm{~min}$ post injection using a Microvette 200 Z-Gel (Sarstedt, Hildesheim, Germany), followed by centrifugation for serum separation and analysis. Samples were stored at $-80^{\circ} \mathrm{C}$ before measurement for insulin levels. Serum insulin levels were measured with Ultrasensitive Mouse Insulin ELISA (Mercodia AB). 


\section{Statistical analysis}

Statistics were carried out using the SPSS-IBM software (IBM, Armonk, NY, USA). Data are typically presented as mean \pm S.E.M., and one-way ANOVA followed by Tukey's post hoc or nonparametric analyses (Kruskal-Wallis, Mann-Whitney U-test) were employed where appropriate to determine statistical significance. For ipGTT, the AUC was used to evaluate the blood glucose response profiles using the trapezoidal rule. ${ }^{42}$ Evaluation of betacell function (\%) and degree of insulin resistance (IR) were calculated using the HOMA as follows: HOMA- $\beta=(20 \times$ fasting serum insulin $(\mu \mathrm{U} / \mathrm{I}) /$ fasting blood glucose $(\mathrm{mmol} / \mathrm{l})-3.5) \%$ and $\mathrm{HOMA}-\mathrm{IR}=($ fasting serum insulin $(\mu \mathrm{U} / \mathrm{l})$ xfasting blood glucose $(\mathrm{mmol} / \mathrm{l}) / 22.5)$, respectively. ${ }^{43}$

\section{ABBREVIATIONS}

$\mathrm{BH} 3, \mathrm{BCl}-2$-homology domain-3; Bmf, Bcl-2-modifying factor; DNHNF1a dominant-negative mutant of rat HNF1 1 ; HNF1 $a$, hepatocyte nuclear factor $1 a$; INS-1, rat insulinoma cells; ipGTT, intraperitoneal glucose tolerance test; NIDDM, non-insulin-dependent diabetes mellitus; RIP, rat insulin promoter; WT, wild type.

\section{ACKNOWLEDGEMENTS}

We wish to thank Professor C. Wollheim for the gift of the RIP-DNHNF-1a mice and Professor Andreas Strasser and Professor Andreas Villunger for the gift of the $b m f$-deficient mice. The authors acknowledge the funding supported by Health Research Board Grant RP/2008/14 and the RCSI Seed-Fund PLASMIR-X (to JHMP and MMB), as well as Science Foundation Ireland Grant 08/IN1/1949 (to JHMP).

\section{AUTHOR CONTRIBUTIONS}

$\mathrm{SP}, \mathrm{MMB}$ and JHMP designed the study; SP researched, analyzed, interpreted the data and wrote the manuscript; $\mathrm{LH}$ researched and analyzed the data; HD researched and analyzed the data and contributed to the manuscript; MMB and JHMP contributed to the discussion and reviewed and edited the manuscript. All authors contributed to critical revision of the manuscript and approved the final version. JHMP and MMB are the guarantors of this work and as such had full access to all the data in the study.

\section{COMPETING INTERESTS}

The authors declare no conflict of interest.

\section{REFERENCES}

1 Fajans SS. Scope and heterogeneous nature of MODY. Diabetes Care 1990; 13 49-64.

2 Byrne MM, Sturis J, Menzel S, Yamagata K, Fajans SS, Dronsfield MJ et al. Altered insulin secretory responses to glucose in diabetic and nondiabetic subjects with mutations in the diabetes susceptibility gene MODY3 on chromosome 12. Diabetes 1996; 45: 1503-1510.

3 Wang $\mathrm{H}$, Maechler $\mathrm{P}$, Hagenfeldt KA, Wollheim CB. Dominant-negative suppression of HNF-1alpha function results in defective insulin gene transcription and impaired metabolism-secretion coupling in a pancreatic beta-cell line. EMBO J 1998; 17: 6701-6713.

4 Emens LA, Landers DW, Moss LG. Hepatocyte nuclear factor 1 alpha is expressed in a hamster insulinoma line and transactivates the rat insulin I gene. Proc Nat Acad Sci USA 1992; 89: 7300-7304.

5 Blumenfeld M, Maury M, Chouard T, Yaniv M, Condamine H. Hepatic nuclear factor 1 (HNF1) shows a wider distribution than products of its known target genes in developing mouse. Development 1991; 113: 589-599.

6 Frain M, Swart G, Monaci P, Nicosia A, Stämpfli S, Frank $R$ et al. The liver-specific transcription factor LF-B1 contains a highly diverged homeobox DNA binding domain. Cell 1989; 59: 145-157.

7 Shih DQ, Bussen M, Sehayek E, Ananthanarayanan M, Shneider BL, Suchy FJ et al. Hepatocyte nuclear factor-1alpha is an essential regulator of bile acid and plasma cholesterol metabolism. Nat Genet 2001; 27: 375-382.

8 Wang H, Antinozzi PA, Hagenfeldt KA, Maechler P, Wollheim CB. Molecular targets of a human HNF1 alpha mutation responsible for pancreatic beta-cell dysfunction. EMBO J 2000; 19: 4257-4264.

9 Yamagata K, Yang Q, Yamamoto K, Iwahashi H, Miyagawa J, Okita K et al. Mutation P291fsinsC in the transcription factor hepatocyte nuclear factor-1 alpha is dominant negative. Diabetes 1998; 47: 1231-1235.
10 Wobser $H$, Düssmann $H$, Kögel D, Wang $H$, Reimertz $C$, Wollheim $C B$ et al. Dominant-negative suppression of HNF-1 alpha results in mitochondrial dysfunction, INS-1 cell apoptosis, and increased sensitivity to ceramide-, but not to high glucose-induced cell death. J Biol Chem 2002; 277: 6413-6421.

11 Hagenfeldt-Johansson KA, Herrera PL, Wang $H$, Gjinovci A, Ishihara $H_{t}$ Wollheim CB. Beta-cell-targeted expression of a dominant-negative hepatocyte nuclear factor-1 alpha induces a maturity-onset diabetes of the young (MODY)3like phenotype in transgenic mice. Endocrinology 2001; 142: 5311-5320.

12 Wang H, Hagenfeldt-Johansson K, Otten LA, Gauthier BR, Herrera PL, Wollheim CB. Experimental models of transcription factor-associated maturity-onset diabetes of the young. Diabetes 2002; 51: S333-S342.

13 Butler AE, Janson J, Bonner-Weir S, Ritzel R, Rizza RA, Butler PC. beta-cell deficit and increased beta-cell apoptosis in humans with type 2 diabetes. Diabetes 2003; 52: 102-110.

14 Lee SC, Pervaiz S. Apoptosis in the pathophysiology of diabetes mellitus. Int J Biochem Cell B 2007; 39: 497-504.

15 Kilbride SM, Farrelly AM, Bonner C, Ward MW, Nyhan KC, Concannon CG. AMPactivated protein kinase mediates apoptosis in response to bioenergetic stress through activation of the pro-apoptotic $\mathrm{BCl}-2$ homology domain-3-only protein BMF. J Biol Chem 2010; 285: 36199-36206.

16 Liadis N, Murakami K, Eweida M, Elford AR, Sheu L, Gaisano HY et al. Caspase-3dependent beta-cell apoptosis in the initiation of autoimmune diabetes mellitus. Mol Cell Biol 2005; 25: 3620-3629.

17 Federici M, Hribal M, Perego L, Ranalli M, Caradonna Z, Perego C et al. High glucose causes apoptosis in cultured human pancreatic islets of Langerhans: a potential role for regulation of specific Bcl family genes toward an apoptotic cell death program. Diabetes 2001; 50: 1290-1301.

18 McKenzie MD, Jamieson E, Jansen ES, Scott CL, Huang DC, Bouillet P et al. Glucose induces pancreatic islet cell apoptosis that requires the $\mathrm{BH}$-only proteins Bim and Puma and multi-BH domain protein Bax. Diabetes 2010; 59: 644-652.

19 Wali JA, Rondas D, McKenzie MD, Zhao Y, Elkerbout L, Fynch S et al. The proapoptotic $\mathrm{BH}$-only proteins Bim and Puma are downstream of endoplasmic reticulum and mitochondrial oxidative stress in pancreatic islets in response to glucotoxicity. Cell Death Dis 2014; 5: e1124.

20 Puthalakath H, Villunger A, O'Reilly LA, Beaumont JG, Coultas L, Cheney RE et al. $\mathrm{Bmf}$ : a proapoptotic $\mathrm{BH} 3$-only protein regulated by interaction with the myosin $\mathrm{V}$ actin motor complex, activated by anoikis. Science 2001; 293: 1829-1832.

21 Hausmann $M$, Leucht K, Ploner C, Kiessling S, Villunger A, Becker $\mathrm{H}$ et al. $\mathrm{BCL}-2$ modifying factor (BMF) is a central regulator of anoikis in human intestinal epithelial cells. J Biol Chem 2011; 286: 26533-26540.

22 Grespi F, Soratroi C, Krumschnabel G, Sohm B, Ploner C, Geley S et al. BH3-only protein Bmf mediates apoptosis upon inhibition of CAP-dependent protein synthesis. Cell Death Differ 2010; 17: 1672-1683.

23 Labi V, Erlacher M, Kiessling S, Manzl C, Frenzel A, O'Reilly L et al. Loss of the $\mathrm{BH} 3$-only protein Bmf impairs $\mathrm{B}$ cell homeostasis and accelerates gamma irradiation-induced thymic lymphoma development. J Exp Med 2008; 205: 641-655.

24 Contreras AU, Mebratu Y, Delgado M, Montano G, Hu CA, Ryter SW et al Deacetylation of p53 induces autophagy by suppressing Bmf expression. J Cell Biol 2013; 201: 427-437.

25 Lau GJ, Godin N, Maachi H, Lo CS, Wu SJ, Zhu JX et al. Bcl-2-modifying factor induces renal proximal tubular cell apoptosis in diabetic mice. Diabetes 2012; 61 474-484.

26 Dennis MD, Shenberger JS, Stanley BA, Kimball SR, Jefferson LS. Hyperglycemia mediates a shift from cap-dependent to cap-independent translation via a 4E-BP1-dependent mechanism. Diabetes 2013; 62: 2204-2214.

27 Orci L, Unger RH. Functional subdivision of islets of Langerhans and possible role of D cells. Lancet 1975; 2: 1243-1244.

28 Pinon JD, Labi V, Egle A, Villunger A. Bim and Bmf in tissue homeostasis and malignant disease. Oncogene 2008; 27: S41-S52.

29 Bosco D, Orci L, Meda P. Homologous but not heterologous contact increases the insulin secretion of individual pancreatic B-cells. Exp Cell Res 1989; 184: 72-80.

30 Hoang DT, Matsunari H, Nagaya M, Nagashima H, Millis JM, Witkowski $P$ et al. A conserved rule for pancreatic islet organization. PLOS ONE 2014; 9: e110384.

31 Gilmore AP. Anoikis. Cell Death Differ 2005; 12: 1473-1477.

32 Ren D, Sun J, Wang C, Ye H, Mao L, Cheng EH et al. Role of BH3-only molecules Bim and Puma in beta-cell death in Pdx1 deficiency. Diabetes 2014; 63 2744-2750.

33 Mollah ZU, Wali J, McKenzie MD, Krishnamurthy B, Graham KL, Fynch S et al. The pro-apoptotic $\mathrm{BH} 3$-only protein $\mathrm{Bid}$ is dispensable for development of insulitis and diabetes in the non-obese diabetic mouse. Apoptosis 2011; 16: 822-830.

34 Zhou YP, Pena JC, Roe MW, Mittal A, Levisetti M, Baldwin AC et al. Overexpression of $\mathrm{Bcl}-\mathrm{x}(\mathrm{L})$ in beta-cells prevents cell death but impairs mitochondrial signal for insulin secretion. Am J Physiol Endocrinol Metab 2000; 278: E340-E351. 
35 Luciani DS, White SA, Widenmaier SB, Saran VV, Taghizadeh F, Hu X et al. Bcl-2 and $\mathrm{BCl}-\mathrm{xL}$ suppress glucose signaling in pancreatic beta-cells. Diabetes 2013; 62: 170-182.

36 Kroemer G. The proto-oncogene $\mathrm{Bcl}-2$ and its role in regulating apoptosis. Nat Med 1997; 3: 614-620.

37 Kluck RM, Bossy-Wetzel E, Green DR, Newmeyer DD. The release of cytochrome c from mitochondria: a primary site for Bcl-2 regulation of apoptosis. Science 1997; 275: 1132-1136.

38 Vander Heiden MG, Chandel NS, Williamson EK, Schumacker PT, Thompson CB. $\mathrm{BCl}-\mathrm{xL}$ regulates the membrane potential and volume homeostasis of mitochondria. Cell 1997; 91: 627-637.

39 Vander Heiden MG, Chandel NS, Schumacker PT, Thompson CB. BCl-xL prevents cell death following growth factor withdrawal by facilitating mitochondrial ATP/ ADP exchange. Mol Cell 1999; 3: 159-167.

40 Reed JC, Jurgensmeier JM, Matsuyama S. Bcl-2 family proteins and mitochondria. Biochim Biophys Acta 1998; 1366: 127-137.
41 Bonner C, Bacon S, Concannon CG, Rizvi SR, Baquié M, Farrelly AM et al. INS-1 cells undergoing caspase-dependent apoptosis enhance the regenerative capacity of neighboring cells. Diabetes 2010; 59: 2799-2808.

42 Andrikopoulos S, Blair AR, Deluca N, Fam BC, Proietto J. Evaluating the glucose tolerance test in mice. Am J Physiol Endocrinol Metab 2008; 295: E1323-E1332.

43 Matthews DR, Hosker JP, Rudenski AS, Naylor BA, Treacher DF, Turner RC et al. Homeostasis model assessment: insulin resistance and beta-cell function from fasting plasma glucose and insulin concentrations in man. Diabetologia 1985; 28: 412-419.

(c) (i) This work is licensed under a Creative Commons Attribution 4.0 International License. The images or other third party material in this article are included in the article's Creative Commons license, unless indicated otherwise in the credit line; if the material is not included under the Creative Commons license, users will need to obtain permission from the license holder to reproduce the material. To view a copy of this license, visit http://creativecommons.org/licenses/by/4.0/ 